\title{
UM SENÃO DIANTE DA JUSTIFICAÇÃO ÉTICA: AMOR FAT/EM NIETZSCHE
}

\author{
Vânia Dutra de Azeredo \\ Pontifícia Universidade Católica de Campinas
}

\begin{abstract}
This paper shows the possibilities of a new ethical perspective having as a point of departure the thought of Nietzsche. We try to show that it is rather impossible to link the moral action to any rational foundation or justification, since the moral action is a result of deep conditions that determine being and acting. We begin with the foundations of moral norms in Hume's and Moore's approaches and then we show three points of the Nietzsche's philosophy that allow us to reject the foundations and at the same time to propose a kind of ethics without the concept guilt, These points are: 1. the rejection of a representative identity; 2. the origin of the judgments good/evil; 3. amor fati as Ethics.
\end{abstract}

Keywords: action, ethics, non-conscious, impulses, perspective.

Resumo: Este artigo apresenta as possibilidades de uma nova perspectiva ética a partir do pensamento de Nietzsche, quer mostrar que há uma impossibilidade de ligar a ação moral a qualquer fundamento ou justificação racional, haja vista que ela é apresentada como resultante de condições profundas enquanto determinantes do ser e do atuar. Partimos da enunciação da problemática concernente ao fundamento das normas morais nas abordagens de Hume e Moore e, depois, apresentaremos três pontos axiais da filosofia nietzschiana que nos permitem, ao mesmo tempo, rejeitar o fundamento e propor uma ética sem culpa, quais sejam, 1. recusa de uma identidade representativa; 2. proveniência dos juízos de valor bom e mau/ bom e ruim; 3. amor fati como ética.

Palavras-chave: ação, ética, não-consciente, impulsos, perspectiva.

Este artigo quer mostrar, a partir de Nietzsche, que há uma impossibilidade de ligar a ação moral a qualquer fundamento ou justificação racional, haja vista que ela é apresentada como resultante de condições 
profundas enquanto determinantes do ser e do atuar. Nesse sentido, partiremos da enunciação da problemática concernente ao fundamento das normas morais nas abordagens de Hume e Moore e, depois, apresentaremos três pontos axiais da filosofia nietzschiana que nos permitem, ao mesmo tempo, rejeitar o fundamento e propor uma ética sem culpa, quais sejam, 1) recusa de uma identidade representativa; 2) proveniência dos juízos de valor bom e mau/bom e ruim; 3) amor fati como ética.

Comecemos por enunciar a indagação alusiva às normas morais: em que medida se pode afirmar que dever fazer algo implica, ao mesmo tempo, em poder apresentar razões acerca dessas realizações no sentido de justificações plausíveis para a escolha feita, ou talvez, para aquilo que, em tese, deveria ser. No domínio do agir, especialmente, há controvérsias marcantes que separam diametralmente as perspectivas que compreendem o agir a partir de atitudes emocionais, recusando, por conseguinte, qualquer tipo de justificação racional para as normas morais, de uma construção explicativa que se proponha a fundamentar as questões práticas, isto é, a reivindicar para as normas morais um estatuto similar ao das proposições descritivas, afirmando que são passíveis de validação. É, de fato, um embate acirrado acerca do agir orientado para fins em termos de uma posição cognitivista ou não-cognitivista que o explique. Não se trata de buscar máximas que vigorem incondicionalmente, mas de pensar em uma conciliação viável entre a postulação de máximas e a sua correspondente justificação.

Ora, as questões referentes, por exemplo, ao que é bom ou ao que é justo são, indiscutivelmente, prementes para a existência humana. Uma escolha nesse nível tem reflexos marcantes na comunidade em que se realiza, haja vista a extensão aplicativa das normas/imperativos que visam a regulamentar as relações entre os homens em uma determinada sociedade. É preciso, entretanto, separar o domínio concreto do reflexivo, pois ainda que no cotidiano as pessoas ajam de acordo com uma compreensão do que é bom ou do que é justo, a problemática reside em explicar essa compreensão e, nesse sentido, tem-se de admitir que as proposições: "O livro é pesado" e "Paulo é bom" são diferentes. Não se trata de uma diferença lógica em termos de forma, pois ambas são redutíveis à fórmula "s é p"; todavia, para além dessa formalização, há um significado e uma função diversos que, em princípio, permitem verificar empiricamente a primeira proposição e não o permitem com relação à segunda, inviabilizando, segundo alguns 
estudiosos, sua justificação. As proposições normativas não podem ser verificadas empiricamente, pois a alusão é feita, via de regra, ou àquilo que deve ser - não há fato ou situação possível que sirva de referencial para a sua demonstração - ou a juízos de valor acerca do que é bom ou justo, o que requer uma prévia determinação de tais juízos. Há, assim, uma impossibilidade de atribuir a essas proposições um valor de verdade, requerendo, em uma perspectiva lógico-semântica, destituí-las de significado.

Nesse sentido, o problema concernente à especificidade das proposições normativas remete à dificuldade de sua justificação. Essa dificuldade aparece tanto em se tomando a proposição isoladamente, como mencionamos acima - embora haja perspectivas que apresentem uma fundamentação pragmático-linguística enquanto dimensão de possibilidade de justificação -, quanto com relação à construção de argumentos. E isso é o que nos interessa aqui, pois, via de regra, algumas proposições éticas, tomemos as naturalistas, restringindo a abordagem a concepção de uma ética evolucionista que correlaciona moral e evolução, acreditando que uma investigação empírica baseada na teoria da evolução esclarece a natureza da moralidade. Observe-se que de imediato somos remetidos a ordens distintas, quais sejam, a natureza e a moral. Tal ética propõe a passagem de uma à outra como ponto decisivo de compreensão do domínio moral. Em que pese a diversidade de críticas que se poderia endereçar a esta perspectiva, nos deteremos em uma que se evidencia pela diferença entre natureza e moral que remete à distinção entre fato e valor, quer dizer, entre dimensões distintas. A problemática reside em tentar sustentar a segunda a partir da primeira, formulando um argumento que derive de um fato ou de uma prescrição.

Voltemos às proposições e as esquematizemos segundo a forma usual:

"s é p"

"s é preferível a p"

"Deves fazer s ou faz s"

As formas apresentadas acima correspondem respectivamente à enunciativa, à preferencial e à imperativa. Todavia, em princípio, as letras $\mathrm{s}$ e p podem designar tanto algo factual quanto valorativo. Forma enunciativa, no primeiro caso, "Pedro é alto", no segundo, "Pedro é justo". Mesma forma, distinto sentido, pois, no primeiro caso, a altura é uma propriedade 
que naturalmente pertence a Pedro, independentemente de necessidade e finalidade. É um juízo factual ou de existência. No segundo caso, enunciamos uma propriedade que só existe em relação a uma necessidade ou finalidade humana e não em si. Daí ela ser valiosa, isto é, enunciar um valor ao invés de um fato. No último caso não apenas se informa acerca de "p", mas se avalia acerca de "p". Com relação à forma preferencial, embora possa ter ou não um conteúdo moral, ela atribui uma propriedade valiosa à medida que estabelece uma preferência entre duas questões ou coisas. Mas, em ambos os casos, a referência pode ser a atos já realizados ou objetos inexistentes como a atos e objetos que, no primeiro caso, se realizam e, no segundo, existem, atualmente.

Ora, a forma normativa ou imperativa difere toto coelo das duas anteriores, pois em juízos do tipo "deves fazer s" (ou faz "s") encontramos uma exigência de realização que não está presente nos primeiros. É um mandamento, exortação, imperativo que tem como fim a realização de algo. Logo, não é expressão de um fato, mas uma exigência de realização, cuja força não fenece mediante sua não realização. Ao contrário, mantêm-se viva, já que não depende do dado de que se cumpra. Daí não ser expressão ou registro de um fato, diferindo completamente de um enunciado factual. Assenta-se num juízo de valor, tendo em vista que o implica. "Deves fazer s" implica "s é bom", por exemplo. Ao estar ligada por implicação a um juízo de valor considera, necessariamente, certa finalidade ou necessidade que confere a propriedade de ser valioso(a). Daí a distância intransponível que se evidencia entre fato e valor, mesmo que, em termos de forma lógica, possa ter ou não um conteúdo moral. É esse conteúdo que nos interessa, uma vez que nos remete a sua efetiva possibilidade em termos de validade ou justificação. Todavia, o que nos interessa expor é a fragilidade da passagem da natureza à moral desde a distinção apresentada entre fato e valor, quer dizer, como é possível passar do âmbito factual para o valorativo sem incorrer em uma falácia. Essa questão nos remete à formulação do problema por Hume e, posteriormente, por Moore.

Ora, no Tratado da natureza humana, Hume faz referência aos sistemas morais em geral, nos quais encontrou um problema referente à passagem de cópulas usuais como 'é' e 'não é' para a utilização de um 'deve' ou 'não deve'. A conexão à qual Hume se refere é a da passagem do ser, nas premissas, para o dever ser, na conclusão. O filósofo escocês considera inconcebível tal relação, cuja mudança, embora imperceptível, 
configura a passagem de premissas factuais para uma conclusão moral. Conforme exposição acima, enunciados ou proposições factuais e morais são distintos, haja vista que um remete ao fato, propriedade natural que pertence a $\mathrm{x}$, enquanto o outro remete ao valor, propriedade não natural pertencente a x. Daí a impossibilidade lógica de derivar um valor de um fato, de premissas factuais chegar-se a uma conclusão prescritiva. Eis o problema da justificação racional dos juízos morais devido à distinção entre ser e dever, isto é, entre aquilo que é e aquilo que deve ser, apresentada por Hume e retomada sob a formulação denominada de falácia naturalista por Moore.

Em Moore, bom não é uma propriedade natural, bom em si mesmo não é definível. As propriedades das coisas boas não são suficientes para definir o que é bom, ele entende que enquanto predicado, ele é indefinível. Bom é uma categoria simples, evidente em si e irredutível a uma propriedade natural. A possibilidade de apreensão de coisas intrinsecamente boas está na suposição de um sujeito moral que apreenda intuitivamente a propriedade simples que as constitui. O filósofo conclui que não é passível de definição qualquer propriedade moral. Daí o erro que se comete quando se associa um objeto natural ao predicado bom, constituindo uma falácia definir bom através de propriedades naturais, fazer isso é justamente formular uma falácia naturalista: “... se a pessoa confunde 'bom', que não é no mesmo sentido um objeto natural, neste caso há razão para denominar

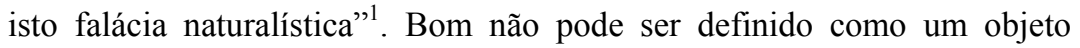
empírico natural. Em vista disso, a crítica de Moore ao naturalismo ético, cuja posição consiste em afirmar que os valores morais podem ser identificados ou reduzidos a uma propriedade natural. Propriedades morais estas entendidas como iguais às propriedades naturais presentes nas explicações científicas das coisas.

Vejamos a exposição de Nietzsche acerca da problemática da justificação desde outro ponto de vista. Comecemos por mostrar que o filósofo alemão não separa ação e representação, pensamento e vida. Isso se explicita em seus textos inclusive como recusa do sujeito fundante do ser, do conhecer e do agir e por aqui, justamente, passaria o rigor de um não

\footnotetext{
1 G. Moore. Princípios éticos. Trad. Luiz Baraúna e Pablo Maricondas. São Paulo: Abril Cultural, 1980, p. 13. (Coleção "Os Pensadores").
} 
fornecimento de referenciais representativos, que aparecem em Nietzsche na compreensão do par ação/representação que se efetiva na postulação de uma identidade representativa de conceitos veiculada pelo juízo lógico.

O conceito, assim como a essência seria desde sempre a tradução de intensidades manifestas pelas particularidades tipológicas em fantasmas. Para entender a noção de fantasma parece interessante recorrer a imagens visuais. No caso em questão, pensa-se que a relação espectador/ator no teatro se presta para tal compreensão. A intensidade é manifesta pela particularidade enquanto nome próprio e, portanto, enquanto vive e atua na relação com os demais, se define pela vizinhança, pelo campo de forças que estariam em relação no palco. A vivência do ator deve ser tomada como única existente, como estado vivido. Todavia, aquele que deixa de viver ou, no caso, de atuar, devido à fraqueza e ao debilitamento, passa para a platéia e inicia um processo de tradução da ação, do estado vivido, das intensidades em sua interioridade. De um lado, busca a apreensão da ação na consciência, de outro, traduz a ação em representação. Surge, então, a noção de essência. Observe-se que ele sai da particularidade e encaminha-se para a generalidade; não existem mais nomes próprios e sim conceitos. $\mathrm{O}$ ator vive no palco, o espectador apreende e funda em sua consciência o que seria ação e, desse modo, fixa-se na representação. Nesse momento, os estados vividos transformam-se em fantasmas.

A observação referente à tradução dos estados vividos em fantasmas, mencionada por Deleuze em "Pensamento nômade, já está presente, de certo modo, no texto nietzschiano quando em Aurora ele faz alusão ao surgimento e desenvolvimento da vida contemplativa, contrapondo posturas divergentes dos indivíduos perante a ação. Isso remete, em cada caso, à constituição de cada um. Tem-se, então, de um lado, aqueles que traduzem a representação em ação e, de outro, aqueles que, por não conseguirem mais agir, se fixam na representação. A ação como traduzida em representação expressaria uma condição favorável em que a força se manifesta em sua plenitude: "o indivíduo seguro da plenitude de sua força procura sempre agir conforme esses juízos e, portanto, traduzir a representação em ação, através da caça, da pilhagem, das sevícias, do assassinato"2 (M/A, Livro primeiro, §42). Em sentido diverso, o indivíduo que tem sua força

\footnotetext{
2 F. W. Nietzsche. Aurora. Trad. Paulo César de Souza. São Paulo: Companhia das Letras, p. 40.
} 
enfraquecida sente-se doente, "suas representações pessimistas se exteriorizam apenas em palavras e pensamentos (...) e seus julgamentos serão julgamentos desfavoráveis" ${ }^{\text {3 }}(\mathrm{M} / \mathrm{A}$, Livro primeiro, §42). Nesse momento, ele inicia um processo de abstração que se reflete na figura que assume de pensador ou anunciador como produto de um seu estado. Daí, "todas as produções de seu espírito devem refletir seu estado, a saber, um acréscimo de seu medo e de seu cansaço, uma diminuição de sua estima pela ação e pelo gozo. O conteúdo de suas produções deve corresponder ao conteúdo de seus humores poéticos, meditativos, sacerdotais: o julgamento desfavorável deve predominar"^4 (M/A, Livro primeiro, $\$ 42$ ).

Observe-se que as citações apontam para uma ruptura entre ação e representação referidas diretamente à plenitude ou não da força. Com isso, se quer assinalar, a perspectiva nietzschiana enquanto recusa a exacerbação da representação como dimensão de plenitude e, de outro, referir essa cisão à distinção entre estado vivido e fantasma. As citações de Nietzsche, apresentando as condições de surgimento da contemplação, assinalam aquilo que constitui o pano de fundo das construções filosóficas que assimilam e expressam essa distinção: a fraqueza, o debilitamento, a impotência. Com isso, se quer demarcar um domínio específico de compreensão e expressão que separa diametralmente o texto e o discurso nietzschiano daquele dos demais filósofos da tradição. Aponta-se como marco referencial distintivo a emergência de uma vinculação entre ação e representação, entre pensamento e vida.

Há uma relação imediata que pode ser requerida para o texto nietzschiano que passa pela exclusão de uma mediação conceitual que vige nas proposições enquanto elementos necessários no processo de inferência de uma lógica da identidade. $\mathrm{O}$ argumento trabalha com conceitos, ato de apreensão em que a interioridade percebe a existência de algo. Posteriormente, os juízos afirmam ou negam a identidade representativa dos conceitos, novamente a interioridade do conceito e da consciência. O processo inferencial se efetiva quando, por meio dessas afirmações de identidades representativas, chega-se ao estabelecimento de outra identidade representativa. Ora, isso é a própria inclusão da representação e postulação

\footnotetext{
${ }^{3}$ Idem, ibidem.

${ }^{4}$ Idem, ibidem.
} 
da interioridade. Não obstante, a maior parte dos textos veiculam essa relação. Isso pode ser tomado como tradução de estados vividos em fantasmas, de nomes próprios, que seriam intensidades em relação, mediados pela interioridade. É preciso notar em que medida a tradução de estados vividos em uma representação não é uma mera formalização que, excluindo a particularidade e a intensidade que se manifesta somente no estado vivido, faz do conceito um fantasma. Não se tem mais a representação traduzida na ação, mas diferentemente emerge a representação como condicionante da ação. $\mathrm{O}$ ator abandona o palco e se faz observador; o texto não veicula forças, apenas as representa e, desse modo, as desnatura. Daí os juízos de valor não poderem ser nem uma propriedade natural e nem algo ao qual se predique o em si, mas o resultado de uma avaliação.

Ora, a genealogia nietzschiana acerca de bom e mau/bom e ruim nos remete a outro tipo de compreensão ao recusar, sumariamente, a possibilidade de tanto o bom ser uma propriedade natural quanto ser "bom em si”, já que resulta de uma interpretação condicionada pela ascensão ou declínio do avaliador.

Na primeira parte de Para a genealogia da moral, Nietzsche se detém a analisar a dupla proveniência dos juízos de valor bom e mau (gut/böse), bom e ruim (gut/schlecht) para, de um lado, explicitar a duplicidade de avaliações, vinculando-as a dois tipos distintos de homem senhor e escravo -, demonstrando, com isso, a existência de duas tendências morais opostas e, de outro, denunciar o erro daqueles que estudaram a moral a partir da defesa de fundamentos, em detrimento da crítica. A duplicidade perpassa o texto nietzschiano, apontando a diferença como elemento constitutivo. Nas análises referentes aos juízos de valor bom e mau/bom e ruim, ao senhor e ao escravo, assim como as duas tendências morais distintas, moral de senhor e moral de escravo, Nietzsche trabalha com o que se poderia chamar de uma disjunção. Existem pólos opostos de avaliação e, consequentemente, juízos de valor e tendência morais divergentes.

Nietzsche apresenta a hipótese de que o juízo bom proviria daqueles que se sentiam como bons, isto é, justamente de homens distintos, poderosos e superiores, que julgavam como boas suas ações sem pensar na utilidade das mesmas, mas com o intuito de diferenciar o seu ser, mais do que o seu fazer, de um ser e fazer baixo e vulgar. Nesse sentido, há uma estreita ligação entre o sentir-se bom e a correspondente avaliação daquilo 
que seria bom, enquanto produção desses mesmos homens. É mister assinalar que o juízo bom não é afirmado como algo que possa valer em si, mas tão somente como algo postulado a partir de um si. O juízo ruim era estabelecido por esses mesmos homens para designar o homem baixo, vulgar, e seu respectivo fazer. O deslizamento do termo ruim para o homem vulgar não era mais do que decorrência da oposição ao seu modo de ser nobre e superior:

... o julgamento de "bom" não vem daqueles aos quais se manifesta a "bondade"! Antes, são os próprios "bons", isto é, os nobres, os poderosos, os homens de condição superior e de espírito elevado, que se sentiram bons e estimaram os seus atos como bons, de primeira ordem, em oposição a tudo o que é baixo, mesquinho, comum e vulgar. ${ }^{5}$

A afirmação da superioridade como elemento denotador implica, necessariamente, uma ligação entre o sentimento e o valor, uma vez que a própria superioridade não provém de uma designação externa, mas primordialmente de um impulso interno. Logo, a referência nietzschiana ao "pathos da distância" como o lugar que possibilita criar valores. O termo lugar, utilizado aqui, quer simplesmente referendar a distinção entre uma exterioridade que sofre e uma interioridade que sente e, por isso, produz. Não cria a partir do externo, mas justamente do sentimento interior de "uma espécie superior de senhor, posta em proporção com uma espécie inferior, com um 'abaixo' - essa é a origem da oposição 'bom' e 'ruim",'. A interioridade constrói a exterioridade pelo estabelecimento de valores, enquanto expressão da avaliação e, portanto, da interioridade. Ora, caso se afirme que a avaliação se configura como expressão de um sentimento interior de distância e superioridade, enfim, de diferença com relação ao outro, ou aos outros, então, consequentemente, não pode haver relação entre a ação e a utilidade. Inclusive o estabelecimento dessa implicação, em Nietzsche, fica determinado somente pelo instinto de rebanho, cuja oposição diametral ao senhor se estabelece pela afirmação de um sentimento de identidade e igualdade entre os homens. Sentimento esse que,

${ }^{5}$ Idem. Para a genealogia da moral. Trad. Paulo César de Souza. São Paulo: Brasiliense, p. 21.

${ }^{6}$ Idem, ibidem, p. 22. 
de um lado, cria uma distância intransponível com relação ao senhor e, de outro, justifica a ligação do bom a ações não egoístas favorecedoras da coletividade:

Deve-se a essa origem que a palavra 'bom', de antemão, não se prende necessariamente a ações 'não-egoistas': como é superstição daqueles genealogistas da moral. Em vez disto, somente com um declínio de juízos de valor aristocráticos acontece que essa oposição 'egoísta' - 'não-egoísta' se imponha mais e mais à consciência humana - é, para me servir de minha linguagem, o instinto de rebanho que, com ela, afinal, toma a palavra (e também as palavras). ${ }^{7}$

Historicamente, essa designação encontra respaldo justamente nas formulações dos moralistas ingleses, em especial na formulação de Bentham. São eles que fazem da utilidade um elemento denotador. É pela utilidade que eles estabelecem o valor. A avaliação, enquanto referida ao que é útil para o maior número, dirime toda e qualquer singularidade em uma coletividade. Ora, se a avaliação nobre principia pelo estabelecimento da distância e da diferença frente ao outro, ao desprezível, a moral que prescreve uma consideração igualitária deverá proceder justamente de uma avaliação vil. Ainda assim, Nietzsche ressalta que o desenvolvimento dessa perspectiva de avaliação só obtém, de fato, efetividade no século XIX. Esse seria o século da decadência por excelência, justamente pelo progressivo mascaramento da diferença através de doutrinas igualitárias.

Para que a hipótese relativa à designação do bom como proveniente dos bons não se dirima no azul, próprio dos ingleses, Nietzsche procede a um estudo da origem ${ }^{8}$ desse juízo através da etimologia. Constata que em todas as línguas a palavra "bom" deriva de uma mesma transformação conceptual. Encontra a palavra "nobre" (vornehm), no sentido de ordem social, como conceito-chave, através do qual se chega a idéia bom (gut), no sentido de privilegiado quanto à alma e, em paralelo, encontra as

\footnotetext{
${ }^{7}$ F.W. Nietzsche. Para a genealogia da moral, I, § 2.

8 Observe-se que a palavra "origem" não designa uma proveniência atemporal de validade incondicional, mas justamente remete a uma postulação de sentido, ao estabelecimento de um valor, que, quando referida à origem, quer significar: Quem cunhou determinado valor? e se o fez, a partir de quê? que valor ele tem?
} 
transformações das idéias de vulgar (gemein), plebeu (pöbelhaft), baixo (niedrig) como desenvolvendo-se até a idéia de ruim (schlecht). Nesse momento, ruim tem apenas a significação de simples, comum, diferente do senhor. Existem apenas elementos distintivos de castas. A Nietzsche importa observar que através das palavras e raízes que significavam "bom", transparece o matiz principal pelo qual os nobres se afirmavam como uma classe superior.

Os termos distintivos do homem nobre designavam tanto a sua ascendência no poder, quanto seu traço típico de caráter. No primeiro caso, cuja ocorrência era de certa forma generalizada, utilizavam os termos "os poderosos, os senhores, os possuidores; no segundo, utilizavam 'os verazes" "9. A designação do nobre como veraz, nesse momento, implica a sua própria realidade, ou seja, o nobre é, posteriormente passa a indicar "os verdadeiros enquanto os verazes" (den Wahren als den Wahrhaftigen $)^{10}$. É nesse momento, segundo Nietzsche, que a palavra passa a distinguir a nobreza e, consequentemente, o nobre frente ao homem comum, cuja designação específica é “mendaz" (der lügenhaften gemeinen Mann) ${ }^{11}$. Percebe-se a dualidade de significação que se expressa como constituição de tipos: um homem nobre, homem veraz, distinto de um comum, homem mendaz. O traço de caráter é o que particularmente interessa a Nietzsche, por indicar o modo de ser daqueles que avaliam.

Mediante as transformações de designações expressas pelas palavras, há de se identificar, também, uma mudança no modo de valorar. Ora, se a palavra "bom" designa num dado momento histórico um significado que posteriormente é transformado, o móvel dessa transformação deve ser buscado numa valoração. É a mudança de avaliação que promove uma mudança de designação e, consequentemente, de significação. Aliás, isso

\footnotetext{
${ }^{9}$ F.W. Nietzsche. Para a genealogia da moral, I, $§ 5$.

10 Idem, ibidem.

11 Nietzsche aponta como porta-voz da distinção designativa da própria nobreza o poeta Teógnis de Megara, cuja palavra que assim expressa seria $\varepsilon \sigma \theta \lambda$ os. De acordo com uma nota constante na tradução para a língua portuguesa da Genealogia da moral por Paulo Cesar de Souza, Nietzsche teria cometido um equívoco com relação à significação da palavra grega. Equívoco esse que, na visão de Paulo Cesar de Souza, não compromete o argumento nietzschiano. Todavia, segue-se parte da referida nota. "Esta afirmação de Nietzsche não é confirmada pela moderna pesquisa etimológica. Segundo Pierre Chantraine (Dictionnaire Etymologique de la Langue Grecque, Paris, 1968), trata-se de uma palavra de origem incerta" (cf. p. 187).
} 
referenda a importância da etimologia para o genealogista, já que lhe possibilita perceber a avaliação por trás da significação e, com isso, as relações de forças que num dado momento exercem domínio. O estudo etimológico permite compreender as organizações e as reorganizações nas relações de potências expressas nas transformações dos juízos de valor; remetendo, necessariamente, à questão 'quem?', formulada do seguinte modo: o que quer aquele que cunhou este valor? $O$ que quer quem transformou essa avaliação? Novamente a questão é referida à vontade de potência enquanto afeto de comando presente nas interpretações e avaliações. A identificação da relação entre as forças, assim como entre as vontades de potência, permite determinar a força que dá o sentido, e a vontade de potência que dá o valor e, com isso, a identificação do valor que se encontrava encoberto.

A argumentação nietzschiana tem em vista a obtenção dos elementos disjuntivos que, ao invés de suprimirem a desigualdade e a diferença, procuram mostrar que ela pertence à realidade, entendendo sempre a realidade como um campo de forças em relação de dominação e subjugação. É essa disjunção veraz/mendaz (wahrhaft/lügenhaft), nobre/desprezível (vornehm/verächtlich) ${ }^{12}$ que está na base da diferença produtora do "pathos da distância", a partir do qual o nobre cunha valores. A busca da significação na etimologia corrobora a distinção nobre-desprezível enquanto referida aos traços de caráter, enfatizando, com isso, a interioridade como produtora. A interioridade é compreendida como impulso movente das valorações, como vontade de potência e, nesse sentido, em oposição a uma exterioridade como movente, a um outro como denotador.

Enquanto o "pathos da distância" cunhou valores, bom e ruim estabeleceram distinções quanto ao modo de ser e, por decorrência, o de valorar. $\mathrm{O}$ bom entre os nobres é distintivo de sua preeminência espiritual, de sua diferença com relação à massa, aos que são distintos deles. Não que incluam no ruim conotações morais relacionadas com a preservação ou promoção do populacho. Nem mesmo tal juízo faz referência ao medo que os ruins possam despertar. Ora, entre os nobres, segundo Nietzsche, o bom é

\footnotetext{
12 No texto Humano, demasiado humano, I, II, $\S 45$, Nietzsche, ao discorrer sobre a dupla pré-história do bem e do mal, estabelece uma relação de sinonímia entre, de um lado, bom, nobre e senhor e, de outro, entre mau, vil e escravo. "Bom e ruim são por um tempo sinônimos de nobre e baixo, senhor e escravo".
} 
quem inspira medo e terror, pois, sendo forte e se impondo aos demais, é digno de ser temido. Já os tipos vis, escravos, são desprezíveis pelo seu próprio modo de ser: são incapazes de sentir orgulho de si e de se perceberem como tendo uma alma elevada. Com isso, há o estabelecimento de uma distinção entre, de um lado, indivíduos fortes e, por isso mesmo, temidos e venerados e, de outro, indivíduos fracos, que pela sua própria constituição são desprezados. Todavia, houve uma transformação com relação à vigência desse modo de valorar. Não obstante o vil permanecer sendo desprezível, as oscilações no decurso da história em termos da proeminência nas relações de potência demonstram ser ele determinante das interpretações e avaliações em diversos momentos. Isso requer uma verificação das condições que tornaram esse fato possível, uma vez que o vil é tido como tal em função basicamente de não criar valores, de dirimir as diferenças, o que, por si mesmo, impossibilitaria a sua ascendência como promotor de interpretações e avaliações que pudessem suplantar as de um homem nobre. Daí a necessidade da genealogia como método de verificação da gênese dos valores, enquanto referidos ao elemento diferencial determinante da avaliação: o nobre e o vil, respectivamente, tanto quando referidos às forças, quanto às vontades de potência.

Tem-se um indicativo da possibilidade de uma dupla valoração para os juízos bom e mau, bom e ruim. O que é o bom quando a interpretação do senhor é determinante? O que é o bom quando a interpretação vil vige? Que constituição cada uma delas expressa? O que promoveu uma mudança? Essas questões já mostram a especificidade da filosofia nietzschiana que, como coloca Deleuze, toma os fenômenos como sintomas, cujo sentido é preciso buscar na força que se expressa:

As diferenciações morais de valor nasceram seja sob uma espécie dominante, que se sentia bem em tomar consciência de sua diferença em relação à dominada - ou entre os dominados, os escravos e dependentes de todo grau. No primeiro caso, quando são os dominantes que determinam o conceito "bom", são os estados de alma elevados, orgulhosos, que são sentidos como o distintivo e determinante da hierarquia. $\mathrm{O}$ homem nobre aparta de si os 
seres em que o contrário de tais estados orgulhosos e elevados chega à expressão: ele os despreza. ${ }^{13}$

Há uma distinção entre bom e ruim (gut/schlecht) e bom e mau (gut/böse). A primeira designação é determinada pelo modo de valorar do senhor, que entende nobre/desprezível como bom/ruim. Na segunda, Nietzsche faz alusão ao fato de haver uma outra origem para bom e mau, referida ao homem vil, que promove uma inversão no modo de valorar nobre-aristocrático. Surgem propriamente os juízos de valor bom e mau (gut/böse), não mais significando nobre e desprezível, mas justamente deslocando a avaliação do modo de ser para a ação. Em vista disso, a referência nietzschiana quanto à aplicação das designações morais primeiro ao homem e só posteriormente às ações. A referência ao homem é o resgate da interioridade, enquanto impulso movente que determina a avaliação, já que a ação expressa essa avaliação, expressa a vontade de potência como fonte de toda ação. $\mathrm{O}$ vil, com certeza, manifesta também a vontade de potência, mas restaria saber como a vontade de potência se manifesta nele. Pelo exposto, conclui-se que o vil não avalia do mesmo modo que o senhor. Contudo, o que o move? O que se encontra encoberto por trás de suas avaliações? Há, na ótica nietzschiana, pelo menos, duas morais:

Note-se desde já que nessa primeira espécie de moral a oposição "bom" e "ruim" significa o mesmo que "nobre" e "desprezível": - a oposição "bom" e "mau" é de outra origem. Desprezado é o covarde, o medroso, o mesquinho, o que pensa na estreita utilidade; assim como o desconfiado, com seu olhar sem liberdade, o que se rebaixa, a espécie canina de homem, que se deixa maltratar, o adulador que mendiga, antes de tudo o mentiroso: - é uma crença fundamental de todos os aristocratas que o povo comum é mentiroso. "Nós, verídicos" - assim se denominavam os nobres na Grécia antiga. Está claro, como sobre a palma da mão, que as designações morais de valor, por toda parte,

${ }^{13}$ F. W. Nietzsche. Para além de bem e do mal, § 260. 
foram aplicadas primeiro a homens e somente mais tarde, por derivações, a ações... ${ }^{14}$

Os juízos de valor bom e ruim sempre tiveram seu estabelecimento associado à nobreza ou à vilania segundo a vontade que estava por trás de determinado tipo de homem. Com isso, o ato seria bom se proveniente de um tipo de homem nobre, e ruim se proveniente de um tipo de homem vulgar. Para os nobres, o estabelecimento de valores refere-se inclusive ao efeito surtido em sua espécie, enquanto possibilidade de sua própria definição. Em um primeiro momento, essa era a maneira de atribuir valor a tais juízos. Mas, em um segundo momento, houve uma inversão, que se estabeleceu quando o bom, outrora sinônimo de nobre, passou a ser atribuído ao tipo vil, e o mau, outrora sinônimo de vil, enquanto ruim, passou a ser atribuído ao tipo nobre. Nesse momento, mau não significa mais ruim:

Aqui está o foco para o nascimento daquela célebre oposição "bom" e "mau" - no mal é sentida a potência e periculosidade, algo de terrível, refinado e forte, que não deixa lugar para o desprezo. Segundo a moral de escravos, portanto, o "mau" desperta medo; segundo a moral de senhores, é precisamente o "bom" que desperta medo e quer despertá-lo, enquanto o homem "ruim" é sentido como desprezível. A oposição chega ao seu auge quando, de acordo com a conseqüência da moral de escravos, também aos "bons" dessa moral acabam por prender-se um bafejo de menosprezo - pode ser leve e benevolente -, porque o bom, dentro da maneira de pensar dos escravos, tem de ser, em todo caso, o homem não-perigoso: ele é bondoso, fácil de enganar, um pouquinho estúpido talvez, é um bonhomme. ${ }^{15}$

A inversão dos juízos bom e ruim/bom e mau é um dado histórico que Nietzsche remete à ascensão dos judeus com relação aos romanos: “...com os judeus principia a revolta dos escravos na moral"16. Mas a

\footnotetext{
14 Idem, ibidem.

${ }^{15} \mathrm{~F}$. W. Nietzsche. Para além de bem e mal, § 260.

${ }^{16} \mathrm{Idem}$. Para a genealogia da moral, I, § 7.
} 
problemática de sua possibilidade requer necessariamente a determinação dos critérios de atribuição desses juízos. A inversão, para o filósofo alemão, se configura por um deslocamento da avaliação. Primeiramente, o valor era proveniente da afirmação da diferença de um homem nobre. Depois, passase a valorar as ações humanas a partir de seu julgamento moral, segundo, basicamente, o reflexo dessas ações sobre a manutenção da igualdade. Ora, uma vez que o valor é, de certa forma, definidor do tipo e definido por ele, pode-se determinar com precisão a que tipo de homem interessava o deslocamento da avaliação. A partir da inversão, houve, de certo modo, a introdução de outros valores - bom e mau - criados para significar a interpretação moral das ações humanas. $\mathrm{O}$ bom era atribuído àqueles homens cujas ações favoreciam a coletividade, o rebanho, enquanto que o mau, ao contrário, era atribuído àqueles cujas ações colocavam em risco a coletividade:

Então para concluir. Os dois valores opostos "bom e ruim", "bom e mau" desencadearam no mundo um combate assustador que durou milênios. Embora há muito tempo o segundo valor se tenha sobreposto ao primeiro, não faltam, hoje, lugares onde se dá uma luta cujo desfecho é incerto. Poder-se-ia mesmo dizer que desde sempre tal luta nunca deixou de acontecer e, consequentemente, de se aprofundar e espiritualizar, de modo que possivelmente não exista hoje um signo mais decisivo de uma "natureza superior", de uma natureza altamente espiritual, que o fato de estarem assim divididos, de existir um real campo de batalha para esses $\operatorname{opostos}^{17}$.

Esse texto de Nietzsche enfatiza, de um lado, a possibilidade de continuidade da disputa dos juízos de valor bom e mau, bom e ruim, mas, de outro, revela a espiritualidade progressiva como contida na própria base da aceitação da disputa desses juízos. Ora, admitir a oposição entre bom e mau/bom e ruim implica mesmo a conformação à metafísica e aos seus elementos representativos, pois, enquanto se toma a dualidade como existente, está subjacente a ela a aceitação dos dois pólos como subsistindo

\footnotetext{
17 Idem, ibidem, I, § 16.
} 
e, com isso, a afirmação, ainda que inconfessa, dos valores transcendentes como possuindo algum estatuto. Daí concluir-se que, em Nietzsche, colocar-se para além de bem e mal, termos utilizados no sentido de bom e mau e, portanto, referidos à inversão do escravo, requer o abandono mesmo da aceitação da oposição desses pares, uma vez que essa oposição se situa ainda no domínio do ressentimento. No último parágrafo da primeira parte de Para a genealogia da moral, Nietzsche afirma: "pois há muito se compreendeu o que é que eu quero, o que é que eu quero justamente com esta perigosa palavra de ordem que dá o título ao meu último livro: Para além de bem e mal. O que pelo menos não quer dizer: 'para além de bom e ruim" "18. Viu-se que, a partir da inversão, houve, de certa forma, o surgimento de outros juízos de valor: o bom e o mau ou bem e mal, criados para interpretar e avaliar moralmente as ações humanas. Nesse sentido, Nietzsche buscaria colocar-se para além dessa interpretação, mas permaneceria admitindo os juízos bom e ruim. Situar-se no domínio do bom e do ruim não implica a admissão da oposição bom e mau/bom e ruim, mas, a partir da exclusão dessa oposição, reconhecer a diferença como fundante do estabelecimento de valores e, nesse caso, propor bom e ruim como expressão mesma dessa diferença e de sua afirmação. Com isso, se está para além da oposição e, portanto, da metafísica e do ressentimento como imperantes, mas não para além da diferença enquanto referida a uma interioridade que organiza a exterioridade mediante o estabelecimento de valores e, portanto, mediante a distinção entre o ascender e o declinar das forças $^{19}$.

\footnotetext{
18 Idem, ibidem, I, § 17.

19 Esta conclusão tem por base a crença na manutenção da existência de algo, pela sua admissão, ainda que esta aceitação seja feita através da negação do fato admitido, e o esclarecimento apresentado por Maurice de Gandillac, em nota à edição de Par-delà bien et mal, feita pela Gallimard, com relação ao uso nominativo e dativo dos termos "bem" e "mal" na língua alemã. Nietzsche utiliza von, que corresponde a de, e não vom, que corresponde a do, implicando, com isso, situar-se para além da própria oposição. Assim, Nietzsche afirmaria Para além de bem e mal e não Para além do bem e do mal, pois jenseits requer um dativo não presente no título, indicando uma possivel intenção na escolha. Em função da relevância da distinção para compreender o pensamento de Nietzsche, segue-se a referida nota: "O leitor terá observado que nos desfazemos, na presente tradução, do título que se tornou tradicional em francês: Par-delà le bien et le mal. A tradução de Jenseits von Gut und Böse põe dois problemas. Primeiro, a ausência do artigo e o fato de que as duas palavras "Gut" e "Böse" estão no nominativo, e não no dativo, nos determinou a traduzir esse título como "par-delà bien et mal", além de bem e mal, isto é, não para além do bem e do mal, mas para além de sua antítese (o que significa que Nietzsche não procura um domínio transcendente a dois valores opostos, mas nega essa oposição
} 
Ora, ao introduzir a força como interpretação, Nietzsche efetua uma reviravolta em termos de interpretação dos existentes. Por um lado, dissolve os conceitos de unidade e substância ao pensar os existentes como multiplicidades de impulsos em luta permanente, cujo termo desfaz-se em um contínuo recomeço que confere ao que devém a característica de um passar, mudar, transformar, sem encontrar unidade ou fixidez, mas impondo incessantemente interpretações. Por outro, ele considera sua exposição como uma interpretação possível, uma vez que supõe não haver outra forma de estar no mundo a não ser interpretando, mas sem a contrapartida de uma unidade subjetiva como intérprete. Quem interpreta é a multiplicidade de vontades de potência que vem a ser o interpretar, o intérprete e a significação que se efetivam enquanto exercer-se. Desencadeia-se, então, a partir dessa outra situação, o seu filosofar como proposição de uma interpretação totalizante, conduzida do primado da interpretação à interpretação do além-do-homem como sujeito ético e do amor fati enquanto sua perspectiva ética.

Nietzsche reconhece que houve muitas tábuas de valores, mas nenhuma delas expressando o vir-a-ser, e é em uma inscrição dessa ordem que se encontra o sentido do seu além-do-homem, enquanto expressão da continuidade do avaliar para além das interpretações anteriores. É a incorporação do trágico como medida da vida que se manifesta no além-dohomem, enquanto reconhece tanto a ausência de responsabilidade de seu ser assim quanto de uma primeira causa no mundo como condicionantes de uma inocência inerente ao mundo e ao homem. Em sua mudança de compreensão e ação, assentada na proposição do sujeito como multiplicidade, está a possibilidade de inscrição de novas tábuas valorativas, à medida que se percebe como avaliador, criador. No limite, como aquele que ao introduzir avaliações impõe perspectivas, fazendo com que, ao sofrimento diante do imponderável, siga o seu testemunho, a sua afirmação, em suma, a aquiescência ilimitada ao que foi e ao que devém. No âmbito dessa aquiescência está, justamente, a percepção das interpretações como

mesma, como nascida do ressentimento dos fracos). Por outro lado, se se trata, às vezes, do bem e do mal como entidades metafísicas (no sentido que Kant fala do mal radical), a fórmula remete muitas vezes (principalmente em toda a primeira dissertação de La généalogie de la morale aos qualificativos "bom" e "mau" (este último termo oposto a "ruim", isto é, a schlecht)". (In: F. NIETZSCHE. Oeuvres philosophiques complètes, v. VII, p. 362). 
formas de o homem estar no mundo. Em Nietzsche, esse reconhecimento é indispensável, enquanto remete à aceitação das perspectivas impostas e ao reconhecimento do movimento de superação que requer a imposição de outras.

Convém mencionar que Nietzsche sustenta uma supremacia da sua interpretação, manifesta no reconhecimento e na incorporação das demais interpretações, isto é, houve outras interpretações que exprimiam uma visão de ser, de conhecer e de agir, incorporando-as no mundo enquanto seu círculo. Por isso, entendermos que o eterno retorno vem justamente expressar o decurso das interpretações, desde a instituição da idéia até a sua suspensão com a imposição da referida doutrina. Reconhecendo com sua instituição a desvalorização do mundo, expressa em termos teóricos e práticos, propõe, com o seu aniquilamento, a revalorização do mundo presente, tanto no seu perspectivismo quanto no amor fati. A inclusão da eternidade no mundo implica a rejeição de uma meta, de um alvo, de uma finalidade e, também, de punição, de condenação e de castigo. É a imanência da eternidade, por um lado, e o reconhecimento da ausência de responsabilidade, por outro, que cindem a compatibilidade entre culpa e ética. Se não há um criador, o decurso do mundo é inocente e, se não há deliberação, o processo da ação é justo. Logo, transparece o ponto decisivo do grande esforço de Zaratustra sobre si com relação à moral, qual seja, ser afirmativo a ponto de justificar mesmo o que passou: trata-se do reconhecimento da necessidade, do destino. Daí ele afirmar que em primeiro lugar está o necessário, sendo o reconhecimento dessa necessidade aquilo que se apresenta como o mais belo e perfeito que se poderá ter. Atingir essa dimensão de afirmação irrestrita da necessidade remete finalmente ao que seria a proposição de uma ética em Nietzsche como amor fati.

Quando Nietzsche aponta para a ausência de garantias em termos de felicidade, prazer, imortalidade e bem-aventurança, ele quer bem mais do que lançar o homem no sem sentido: trata-se de resgatar a sua potencialidade de criador de si e do mundo. Impondo perspectivas, ele se torna aquilo que ele é: um criador de valores. Eis o motivo que faz convergir crítica e construção no domínio dos valores. A crítica não nega a presença das demais interpretações no curso do tempo, nem mesmo a contraposição visa ao seu excluir. Ao contrário, a derradeira filosofia do autor de Assim falava Zaratustra conduz à afirmação dessas interpretações; 
mesmo o cristianismo vem a ser uma forma de o homem estar no mundo ao dotá-lo de valor. Se o filósofo alemão rejeita, em conjunto, as suas avaliações devido à transposição do valor ao plano imaginário, afirma sua presença no círculo mundano de interpretações: tanto o eterno retorno contempla a presença do sim ao conjunto de interpretações que negaram a efetividade, isto é, que introduziram a dualidade de mundos, e do sim especial de Nietzsche enquanto proponente de uma interpretação que visa a ampliar as perspectivas quanto o seu Übermensch manifesta a aquiescência às diversas interpretações, por reconhecer o seu vir-a-ser desde aquilo que ele é.

Os conceitos de Übermensch e amor fati estão estreitamente relacionados. Se o primeiro exprime a travessia trágica do criar e do destruir na ordem de uma aquiescência profunda, a mesma aquiescência que liga Nietzsche, Zaratustra e Dionísio, o segundo elucida a tragicidade da travessia por resgatar os motivos não conscientes na base dos sentidos e valores que, ao conferirem gratuidade ao agir, remetem à mesma anuência. A intenção torna-se condição, o dever converte-se em imposição de perspectiva e o seu ser assim transmuda-se no movimento constante de seu vir-a-ser como fatum. O amor fati exprime a anuência à necessidade que vige em profundidade, ao reconhecer, na base das interpretações, um certo destino. A luta entre os impulsos introduz interpretações que revelam aproximadamente um plano desconhecido governado pelo pensar, querer e sentir que atravessa o corpo humano e impõem uma perspectiva de corpo social. Se não há causa primeira, também não existe razão última. Ao remeter a condição humana tão-somente às suas inclinações que manifestam necessidades, o amor fati conduz a afirmação do caráter fortuito da própria existência à sua singularidade, casualidade e finitude. É a aceitação da necessidade independentemente de justificativas que resgata a condição trágica do humano, na aquiescência àquilo que se é enquanto necessidade do que se vem a ser, no domínio das interpretações impostas. Enquanto interpretação ética, o amor fati expõe o processar-se da ação no homem como uma interpretação do próprio agir. Enfim, o percurso nietzschiano da dissolução da metafísica à ética do amor fati excluiu dos domínios interpretativos a noção de fundamento e conduziu à incompatibilidade entre culpa e ética. Eis o sentido do riso que atravessa Zaratustra.

Mas, Nietzsche também se inclui entre os "criadores" do mundo como filósofo. O conjunto da sua filosofia, particularmente a que se inicia 
em Assim falava Zaratustra, é uma leitura do mundo, em seu conjunto, que se reconhece como perspectiva. O percurso dos existentes, enquanto multiplicidades de vontades de potência, ao amor fati deve-se ao reconhecimento de que não há outro modo de estar no mundo exceto o interpretante. Por isso, a aquiescência profunda endereça-se ao conjunto de interpretações postas no tempo, mesmo ao cristianismo, pois constituem formas de o homem situar-se no mundo desde a atribuição de determinados predicados provisórios. Remete igualmente à assimilação das condições dos existentes que introduziram essas interpretações. Querer o necessário é querer, ao mesmo tempo, as condições e as interpretações, pois Nietzsche não distingue signo, significante e significado. Logo, as condições são as interpretações sempre, estritamente, perspectivas. Estar no mundo, desde essa compreensão de que só há sentido e valor, quer dizer, rejeitar a existência de fatos e fundamentos enquanto predicados do mundo e da vida, requer o reconhecimento da finitude humana enquanto sua irrecusável condição, que faz do introduzir interpretações e do suportar o seu caráter finito a grandeza no homem. A criação nietzschiana consistiu em dissolver a metafísica e prescrever a aceitação incondicional das formas através das quais o homem se situou no mundo, ou seja, por meio da afirmação irrestrita das suas interpretações, mediante a introdução de uma interpretação mais abrangente, que reconhece, nas forças, no além-dohomem e no eterno retorno a introdução de uma perspectiva que conduz à aceitação incondicional da vida. Com a doutrina do eterno retorno, ele estanca o processo de progressão da idéia que prescrevia a "mendacidade ante o necessário", para remeter ao "nada querer diferente, seja para trás, seja para a frente, seja em toda a eternidade". Através do amor fati, Nietzsche resgata o dizer sim à vida mesma e conduz o homem ao eterno prazer do vir-a-ser, mediante a simplicidade do criar e do destruir que o faz:

Zaratustra desceu a montanha sozinho e sem encontrar ninguém. Mas, quando chegou às florestas, deparou repentinamente com um velho, que deixara a sua sagrada choupana para ir à procura de raízes no mato. E assim falou o velho a Zaratustra:

Não me é desconhecido esse viandante; passou por aqui há muitos anos. Chamava-se Zaratustra; mas está mudado. (...) 
Sim, reconheço Zaratustra. Puro é seu olhar e não há em sua boca nenhum laivo de náusea. Não será por isso que caminha como um dançarino?

Mudado está Zaratustra, tornou-se uma criança, Zaratustra despertou...

\section{É possível construir uma interpretação ética sem recorrer à idéia de} natureza ou de constituição humana, sem remessa à justificação ou à fundamentação, mas enquanto expressão de uma dada condição de vida. Esse é o caminho para a compreensão de uma outra perspectiva ética, em Nietzsche, enquanto amor fati $^{20}$. Por um lado, ele admite haver uma necessidade, vigendo em profundidade que prescreve as avaliações manifestas através de uma linguagem conceptual. Embora não se tenha acesso às avaliações que se processam aquém da comunicação, Nietzsche

${ }^{20}$ Há de se mencionar que existem outras proposições de uma ética em Nietzsche. Considerando que a crítica de Nietzsche à moral remete à sua forma atual, Haar identifica nessa filosofia a presença de uma ética. Mas nela reconhece, enquanto a remete à afirmação dionisíaca do mundo, algo de sagrado. Ela estaria relacionada ao ideal de uma humanidade futura, bem como a tudo o que porta o porvir, expressando uma religião do sim. É de outra forma, porém, que interpretamos uma ética em Nietzsche. Diferentemente de uma religião do sim, vemos o amor fati enquanto ética nietzschiana desde a exposição de uma perspectiva acerca do agir que o remete a determinações profundas. É por reconhecer, nas formulações éticas, a exclusão das inclinações humanas que o filósofo de Sils Maria introduz o amor ao necessário como afirmação da necessidade que vige em profundidade, desde uma perspectiva acerca do agir que se reconhece como perspectiva. Em Peter Berkowitz, encontramos uma leitura que, como a nossa, considera a proposição de uma ética como questão central no pensamento do autor de Assim falava Zaratustra. Denominada de ética da criatividade, tal exposição apresenta uma forma concreta de vida à qual devem ajustar-se os que querem ser criadores em vivendo, ao mesmo tempo, uma ética de criatividade e de autodeificação. Baseada no conhecimento metafísico de que Deus está morto, a meta de uma vida boa torna-se, simultaneamente, a liberação e a capacitação da vontade criativa. Seguimos um caminho diverso do trabalhado por esse autor, ao afirmarmos ser a compreensão dos existentes como multiplicidade de impulsos que fornece a Nietzsche elementos para introduzir uma nova compreensão do agir. Como a liberdade, nesse âmbito, é o vencer uma resistência, encontramos a presença de uma legislação que, vigendo em profundidade, regula estimativas e exprime o que se é. Em nossa compreensão, o amor fati como ética em Nietzsche manifesta a aquiescência profunda às interpretações introduzidas enquanto se reconhece a necessidade presente na luta entre os impulsos que introduzem interpretações. Existem outras formas de reconhecimento da presença, não propriamente de uma ética, mas de uma regra prática ou de um tipo de imperativo no pensamento nietzschiano, mas são pautadas exclusivamente pela doutrina do eterno retorno. A formulação, apresentada por Nietzsche em A gaia ciência, "'Você quer isso mais uma vez e por incontáveis vezes?"' (FW/GC § 341) serviria de base, por exemplo, para a introdução de uma lei prática, na visão de Deleuze, e de um imperativo existencial, na ótica de Magnus. Ao entendermos o eterno retorno como círculo mundano de interpretações, vemos sua inclusão na filosofia de Nietzsche ser determinada pela suspensão da progressão da idéia na História da Filosofia, ao invés da introdução de uma lei prática. 
atribui a elas um papel determinante nas avaliações conhecidas. São elas que impõem um modo de avaliar segundo a precisão orgânica. Em vista disso, reiteradas vezes ele relaciona o quanto de potência que se é com o lugar que se ocupa. No limite é este quanto de potência que, legislando em silêncio, situa a ação humana. Com o amor fati, o filósofo retoma o conceito de necessidade como destino, isto é, entende que o destino da existência humana é determinado por avaliações às quais nos falta competência para acessar. Em um fragmento de 1880, ele afirma: "Como todos os nossos atos são necessidades absolutas e de igual modo coisas absolutamente desconhecidas para nós, então todo o: deves fazer isso incondicionalmente são palavras ao vento" ${ }^{21}$, acrescentando, na seqüência, a impossibilidade de nosso controle sobre o querer: "Nem podemos de forma diferente do que devemos, nem nos é possível controlar em cada caso singular se algo aconteceu que deveríamos fazer" ${ }^{, 22}$.

Professar o amor ao necessário, nesse âmbito, é afirmar a necessidade que vige em profundidade desde a introdução de uma perspectiva acerca do agir, que é, em muitos sentidos, indeterminado. É reconhecer que o desconhecido regula o conhecido e que dele somente à necessidade é dado ascender. Por isso, querer amar, doravante, o que é necessário aparecer como única atitude compatível com a competência humana diante do próprio agir. Não determiná-lo com vista a algo, mas interpretá-lo desde o que se manifesta. O amor fati, enquanto interpretação ética, é a exposição de como se processa a ação no homem enquanto interpretação do próprio agir, pois não há como atingir um fundamento. Se Nietzsche afirma que esta será a sua moral, é porque entende o agir desde uma inocência intrínseca manifesta pela impossibilidade de determinação de suas causas. Inocência essa proveniente da própria necessidade do agir, cuja assimilação dá-se mediante o sentimento de sua aceitação.

Transparece, nesse momento, a primeira característica de uma ética nietzschiana: o reconhecimento de que o agir carece de fundamento. Daí ele prescrever o amor ao fatum enquanto sentimento de aceitação da necessidade que independe de justificativas. Não há uma causalidade

\footnotetext{
${ }^{21}$ Idem, Aurore. Pensées sur les préjugés moraux. Trad. Julien Hervier, Paris: Gallimard, 1982, p. 487. (Oeuvres philosofiques complètes, v. IV).

22 Idem, ibidem.
} 
exterior que o explique e tampouco uma causa primeira ou razão última. A ação humana é desprovida de uma razão suficiente que a possa sustentar. Efetivamente, não há, para Nietzsche, uma causa que a faça ser, mas uma explosão de força que não admite dissociação entre causa e efeito. A necessidade do agir enquanto imposição de força exclui terminantemente a necessidade de uma causa. Ao contrário, o caráter fortuito da ação é que ganha relevo, pois, por mais que uma necessidade instintual seja determinante, a impossibilidade de conhecê-la ou de precisá-la torna a sua manifestação sem fundamento, já que se está sempre no domínio da interpretação. No limite, o que Nietzsche percebe nesse jogo entre profundidade e superfície é que o agir não tem um porquê, uma razão de ser, nem tende a um fim. É a essa carência de justificativas que o termo 'fortuito' remete.

Simultaneamente, o acaso e a necessidade estão presentes no agir em Nietzsche, pois o acaso expressa o caráter fortuito das combinações de forças. A multiplicidade de vontades de potência, que o filósofo interpreta enquanto acontecer, corresponde ao céu acaso: "Em verdade é uma benção e não uma blasfêmia, quando eu ensino: 'Acima de todas as coisas está o céu acaso, o céu inocência, o céu casualidade, o céu arrojo" ${ }^{\text {"23 }}$, escreve em Assim falava Zaratustra. Mas existem os lances de dados jogados no céu acaso que determinam as combinações possíveis entre as forças. Cada lance de dados marca a combinação que se dá num e noutro lances. A necessidade aparece, ao mesmo tempo, no lance de dados e na combinação, isto é, vige a necessidade de novos lances de dados, no sentido de outras combinações de forças que, constantemente, se deslocam, o movimento lhes é inerente, e na interpretação que resulta da combinação proveniente da luta entre as forças. Assim, acaso e necessidade não são conceitos contraditórios no pensamento nietzschiano, mas complementares, já que é a presença do acaso que remete a necessidade apenas à combinação. Do contrário, Nietzsche cairia no conceito de uma necessidade natural que dirigiria não as coisas, mas os impulsos, forças, vontades de potência. Nesse caso, o existente é pensado como uma unidade à qual determinada necessidade é posta e não como pluralidade cuja combinação casual impõe uma interpretação necessária.

${ }^{23}$ Idem, Assim falou Zaratustra. Trad. Mário da Silva. 2a ed. São Paulo: Civilização Brasileira, 1981, p.172. 
Necessário é retirar a necessidade do conceito dos existentes, e isso Nietzsche faz ao situar as combinações de forças no céu acaso. Não é a necessidade que as dirige, mas o acaso, ainda que haja a presença da necessidade enquanto produto da combinação de um lance casual. Compreender o agir em Nietzsche, desde a vontade de potência, é entender a distinção entre uma necessidade inerente à qual o filósofo quer ultrapassar e uma necessidade resultante das lutas entre as forças, que se concilia com o acaso. O amor fati exprime a assimilação do resultado das lutas e não de sua inerência às forças.

A ação, por conseguinte, não se desencadeia com vistas a cumprir determinados fins. Desencadeia-se tão-somente de acordo com a necessidade resultante da combinação de forças. Mas, há de se acentuar que, seja pensando a ação desde o acaso das combinações de forças, seja da imposição de perspectiva necessária resultante da combinação, a falta de fundamento concerne a ambas. Ao retirar o fundamento da ação, Nietzsche ataca diretamente as construções éticas que a assentam seja no domínio de uma máxima incondicional, seja no da projeção de um ideal. A rejeição de uma tendência inerente à ação, enquanto motivo interno regido por uma natureza universal pertencente a todos os homens, é substituída pela necessidade orgânica de agir de tal ou qual modo. Necessidade esta que, ao pôr em relevo o interesse das forças por um plus de potência, confere à condução instintual a base do agir, retirando o primado de uma possível razão legisladora. A própria noção de base do agir é decomposta pelo caráter fortuito das combinações, não havendo como desmembrar a ação a partir de uma causalidade anterior. O homem é posto por Nietzsche no mundo desde o desconhecimento de um fundamento. O que conta são as inclinações humanas: seus impulsos, enquanto manifestando necessidades, introduzem interpretações.

Se entendermos ética como as construções explicativas do agir elaboradas na tradição do pensamento ocidental, podemos relacionar o termo amor fati ao termo ética, em Nietzsche, desde a perspectiva da necessidade e da afirmação dessa necessidade enquanto interpretação. Com o primeiro, ele designa o sentimento de aceitação incondicional do que se fez não apenas no instante; porém, na dimensão de um retorno eterno. Com o segundo, simultaneamente a mudança de atitude, que se processa no homem quando ele deixa de julgar a vida passando a afirmá-la, e o reconhecimento de que, na base do seu agir, há uma determinação profunda 
que não lhe permite julgá-lo, mas apenas afirmar a interpretação introduzida. Ao afirmar a vida sem julgá-la, o homem passa a manifestar uma aquiescência profunda diante do que foi, do que é e do que será, convertendo a assimilação da vida em um profundo amor ao destino. Sob outro aspecto, a mudança de atitude é expressão das condições do homem que avalia enquanto produto das avaliações que se dão em profundidade, expressando a necessidade que o faz ser: "A aprendizagem nos transforma; faz como toda alimentação, que não apenas 'conserva'-: como bem sabe o fisiólogo. Mas no fundo de todos nós, 'lá embaixo', existe algo que não aprende, um granito de fatum..."24, escreve Nietzsche em Para além de bem e mal.

Assim, uma segunda característica de uma ética em Nietzsche, relacionada diretamente à primeira, é o reconhecimento da presença de uma determinação profunda do agir como imposição de perspectivas. A admissão de que há um 'granito de fatum' por trás das avaliações conhecidas enquanto seus efetivos regentes: "as formas conscientes de nosso querer, de nossa sensibilidade, de nosso pensamento estão a serviço de um querer, de uma sensibilidade e de um pensamento bem mais amplos" $^{\$ 25}$. As perguntas e respostas que se podem formular já manifestam esse plano decisivo do querer, do pensar e do sentir; já expressam uma interpretação. Nietzsche parte do conceito de vontade de potência para expor o agir. Se os julgamentos de valor são decisivos em termos do que se aceita e da forma como se aceita, esses julgamentos são remetidos à vontade de potência que, para o filósofo, os inspira e regra. Por isso, a moralidade efetiva que o homem porta em seu corpo é a expressão das lutas e hierarquias que se dão entre as diversas vontades de potência. Também a moral conceptual que rege um determinado grupo é, igualmente, inspirada e regrada pela vontade de potência. Em ambos os casos, tem-se interpretações. Todavia, a moral conceptual visa ao grande número enquanto a moral encarnada no corpo, a multiplicidade de tu deves que se exercem no corpo, manifesta a singularidade de cada existente. Entretanto,

\footnotetext{
24 Idem, Para além de bem e mal. Trad. Paulo César de Souza. 2a ed. São Paulo: Companhia das Letras, 1996, p. 139.

25 Idem, Ibidem, Fragments posthumes automne 1884 - automne 1885. Trad. Michel Haar e Marc B. de Launay, Paris: Gallimard, 1982, p. 190. (Oeuvres philosofiques complètes, v. XI).
} 
essa singularidade é mascarada, na ótica de Nietzsche, por uma moral canônica.

Quando as morais explicam o agir, o dever e o conjunto da sua respectiva moral dirigindo-se à totalidade dos homens, o fazem desde a pressuposição de uma igualdade constitutiva deles que já expressa uma interpretação. Por um lado, essa pressuposição já é um cânon moral que determina como o homem deve ser enquanto natureza humana, o homem. Por outro, exprime a moral vigente nas lutas de um corpo que busca a sua conservação enquanto impõe sua perspectiva. É o julgamento de que a igualdade viabiliza a sobrevivência de um maior número que determina a sua associação, bem como as prescrições igualitárias. $\mathrm{Na}$ visão de Nietzsche, como há uma moralidade efetiva no corpo, há um número de "tu deves" que, continuamente, se manifesta na regência dos postos de comando e de obediência, na luta entre as vontades, esta moral mais relevante deve ser levada em conta mais do que a moralização do conceito. Que tipo de vida quer uma moral ao partir já de determinado cânon moral? Mais especificamente, que tipo quer uma moral ao adotar determinadas prescrições? Nesse caso, não há exceções, a moral conceptual visa a um tipo que manifesta a necessidade presente na profundidade mesmo na associação entre os homens. Toda moral, em Nietzsche, visa a um tipo e as necessidades de suas inclinações formam um tipo. Assim, o tipo é determinado pelos sistemas de vassalagem nele presentes e a moral conceptual, pela tentativa de preservá-lo ou não.

Encontramos, em Nietzsche, um conceito de dever que se relaciona, também, com a necessidade que vige em profundidade. É nesse conceito que contamos encontrar a ligação entre o fatum e a formação. Distinto de uma noção abstrata de dever que prescreveria aquilo que "deve ser", uma obrigação moral considerada nela mesma, o conceito nietzschiano de dever remete ao conceito de obediência incondicional. É por entender que há uma série de "tu deves" regulando as relações entre as múltiplas vontades de potência que o filósofo percebe na natureza, entendida como campo de batalha da luta entre os impulsos, um imperativo que prescreve a obediência enquanto condição de plenitude orgânica: “"Deves obedecer seja a quem for, e por muito tempo: senão perecerás, e perderás a derradeira estima por 
ti mesmo'- esse me parece ser o imperativo categórico da natureza"26, escreve Nietzsche em Para além de bem e mal, contrapondo o que entende como imperativo da natureza à abstração imposta pelo imperativo categórico kantiano que se dirige ao indivíduo ${ }^{27}$.

A perspectiva de que há uma necessidade que vige em profundidade inviabiliza a postulação de qualquer imperativo categórico, mas tãosomente condicional enquanto respeita o introduzir de interpretações que se manifesta em profundidade e reconhece no imperativo condicional a possibilidade de uma interpretação acerca do agir. Ao endereçar a obediência ao inteiro bicho homem, a $o$ homem, Nietzsche conecta as características das lutas entre as vontades de potências que, entendidas desde as relações de mando, compõem o homem com uma formação social do inteiro bicho homem, desde a transposição dos vínculos corporais aos sociais. Trata-se de pensar que o mesmo tipo de relação hierárquica entre quem manda e quem obedece em um corpo seja a base para o estabelecimento de uma hierarquia em um corpo entendido socialmente. Por isso, a obediência não se dirige ao indivíduo, especialmente enquanto pondo a si mesmo a possibilidade ou não de obedecer a uma determinada prescrição, mas engloba os povos e o homem a partir do "deves obedecer" que o forma de tal ou qual modo. Ou a obediência conduz a uma hierarquia

\footnotetext{
${ }^{26}$ Idem, Para além de bem e mal. Trad. Paulo César de Souza. 2a ed. São Paulo: Companhia das Letras, 1996, p. 87.

${ }^{27}$ Bernd Magnus também reconhece um imperativo presente na filosofia de Nietzsche, mas a partir da doutrina do eterno retorno. Por concernir apenas ao indivíduo, ao invés de ser categórico, é existencial. Ao rejeitar a necessidade de pensar no valor de verdade da doutrina enquanto cosmologicamente supõe a verdade e normativamente se age como se fosse verdade, Magnus formula um imperativo pluralista que não supõe a universalidade da lei, mas vale para cada um. Não determina o que se deve desejar em termos de vida, mas sim a necessidade de desejar a vida: "O retorno (e sua verdade real ou possível) é uma representação visual e conceptual de uma atitude particular em relação à vida" (MAGNUS, Bernd. Nietzsche's existential imperative. Blomington \& London: Indiana University Press, 1978, p. 142). Na leitura de Gilles Deleuze, a filosofia de Nietzsche dirige suas teses centrais à dialética. Ainda assim, reconhece no seu pensamento uma regra prática tão rigorosa quanto a kantiana. É o eterno retorno entendido, como pensamento ético e seletivo que apresenta uma nova formulação da síntese prática: "O que tu quiseres, queira-o de tal modo que também queiras seu eterno retorno" (DELEUZE, Gilles. Nietzsche et la philosophie. Paris: PUF, 1970, p. 77). Nosso imperativo, diferentemente de Magnus e de Deleuze, é condicional por prescrever condições de plenitude e por se apresentar como uma interpretação. Por outro lado, em nossa ótica, a presença de uma ética, em Nietzsche, não está na atribuição de uma regra ao eterno retorno, seja entendida como imperativo existencial ou regra prática, mas na aceitação incondicional da vida expressa no amor fati que supõe a compreensão do eterno retorno.
} 
que confere plenitude orgânica ou, em sua ausência, a uma desagregação completa dos impulsos. Todavia, é condição de plenitude a presença da hierarquia, tanto entre os órgãos quanto entre os homens, assentada no conceito de obediência incondicional. Não importa ao que se obedece desde que se obedeça: "toda a moral sadia, é dominada por um instinto de vidaalgum mandamento de vida é preenchido por um determinado cânon do 'deves' e 'não deves'..."28, escreve Nietzsche.

O termo moral, nos textos de Nietzsche, aplica-se, ao mesmo tempo, ao âmbito fisiológico e social, à regulamentação vigente entre as ínfimas partes que compõem o organismo e à hierarquia estabelecida entre os homens. Enquanto destina-se à regulação entre os impulsos, o filósofo confere-lhe a significação de elemento regulador do comportamento dos instintos $^{29}$. As morais seriam, assim, do ponto de vista fisiológico, tãosomente formas de expressar a hierarquia presente entre os impulsos, as interpretações que se dão nas profundezas. Os estados morais são entendidos, nesse sentido, como estados de perspectivas fisiológicas. Sob outro aspecto, a moral aparece, na ótica do filósofo, como a forma a partir da qual os homens se hierarquizam. As hierarquias entre os homens e a avaliação de tudo o que concerne ao humano são remetidas à moral enquanto uma espécie de doutrina das avaliações humanas. Nesse caso, as interpretações conceptualizadas expressam as avaliações que se processam em profundidade como estimações para o que concerne ao humano. Operando, aparentemente, em um duplo registro, Nietzsche entenderia, por um lado, a moral como a regulamentação que se processa em profundidade enquanto ordenação fisiológica entre os impulsos e, por outro, como regulação das valorações humanas no âmbito social. Contudo, da compreensão das condições fisiológicas dos impulsos no homem, emerge, para o filósofo, o entendimento de seu mundo valorativo enquanto promoção ou obstrução da vida. Efetivamente, não há uma oposição entre as dimensões fisiológica e social da moral, porque a moral conceptualizada expressa a hierarquia entre os múltiplos impulsos e a tentativa de manter ou

${ }^{28}$ F.W. Nietzsche. Crepúsculo dos ídolos. Trad. Paulo César de Souza. São Paulo: Companhia das Letras, 2006, p. 36.

${ }^{29}$ Ver também Para além de bem e mal, § 19. 
ultrapassar essa hierarquia, desde uma condição moral enquanto imposição de perspectiva.

Nesse sentido, acreditamos que uma ética, em Nietzsche, retoma os traços de caráter na determinação do agir em uma outra dimensão, uma vez que remete à profundidade como determinadora das avaliações e interpretações. É a luta entre as vontades de potência processadas aquém da comunicação que prescreve aquilo que vem a ser como sentido e valor, consoante ao filósofo, enquanto aquilo que vem a ser desde a perspectiva de sua fisiologia. É nesse âmbito que se dá a interpretação que, independente de intérprete impõe uma perspectiva. Ainda que haja a sua conceptualização enquanto tentativa de um tornar comum as avaliações que se processam em profundidade e às quais não se tem acesso via linguagem, são elas que se manifestam sempre que sentidos e valores são introduzidos. A linguagem torna comum processos eminentemente singulares que, ao serem traduzidos, exprimem apenas aproximadamente as avaliações, desde a diferença entre os tipos. Por isso a pressuposição de uma igualdade entre os homens rechaçaria a mínima possibilidade que se tem de apreender, através da diferença, a singularidade da ação humana. O que Nietzsche retoma é o sentido de êthos como a base da práxis, isto é, o êthos nietzschiano corresponde às lutas entre as vontades de potência que se processam em profundidade. Esse é o lugar de onde brota o agir humano, lugar esse que está no homem mesmo e que exprime as lutas que o compõem. É do êthos, enquanto traços de caráter remetidos à vontade de potência, que emanam os atos singulares do homem, em Nietzsche, enquanto interpretação.

A sua ética é a do modo de ser do humano lançado no mundo sem sentidos prévios, cujo caráter do homem, entendido desde a luta entre vontades de potência que impõe uma perspectiva, dota-o de sentido e valor. Nesse caso, Nietzsche distancia-se da compreensão do caráter como modo de ser que se vai adquirindo ao longo da existência. Não se trata da retomada de uma perspectiva aristotélica, que vê o caráter ser adquirido mediante os hábitos. Em Nietzsche, não são os hábitos que determinam o caráter, mas o caráter que determina os hábitos, isto é, a composição humana desde as lutas vigentes em seu corpo, entendidas enquanto caráter, determinam o costume e a moral. Há uma necessidade que vige em profundidade como detentora daquilo que vem a ser. A ética manifesta-se, por conseguinte, desde o modo de vir-a-ser que exprime as lutas entre as vontades de potência. No limite, é ao granito de fatum que Nietzsche remete 
sentido, valor, hábito, costume, etc. Efetivamente, o pensador alemão introduz com a ética do amor fati, uma nova relação do homem com o bem e o mal, a partir da retomada, em outra dimensão, dos pressupostos éticos da ligação social, desde a introdução de determinações não-conscientes e singulares no agir enquanto imposição de perspectivas. Se o entendimento e a compartilha do sentido e do valor supõem a inscrição em uma cadeia de interlocuções, a sua produção provém das lutas que se processam em um corpo singular. Daí a impossibilidade, em seu discurso, de uma ética universal que vigore incondicionalmente.

Ora, além da ausência iniludível de fundamento e das determinações profundas como regentes, duas questões são prerrogativas para uma ética em Nietzsche, quais sejam, a compreensão de que não há uma igualdade constitutiva do homem e a admissão da presença da hierarquia, tanto entre os impulsos quanto entre os homens. Diferença e hierarquia estão diretamente relacionadas, pois a dessemelhança entre homem e homem sustenta a hierarquia entre eles. Da mesma forma que a multiplicidade organizada em um corpo não pode ser encontrada em outro, o conceito de igualdade não encontra referente na efetividade, no campo de luta entre as diversas vontades de potência. Ainda que a luta esteja presente em todas as formas de vida e a hierarquia resultante da luta seja a manifestação das relações de mando e obediência que se processam em um corpo, a sua composição não é encontrada em outro. Caso fosse, teria de haver uma estabilidade entre os adversários, visto que a definição de igualdade implicaria a impossibilidade da disputa desde a diferença entre dominador e dominado. Com a inserção da igualdade no âmbito de sua interpretação fisiológica, o conceito de luta, enquanto movimento de disputa constante presente nos organismos, perde o sentido. O mesmo se processa caso se pense na igualdade permeando as relações sociais, pois a disputa entre os homens também deixaria de existir. Em vista disso, a igualdade em Nietzsche só aparecer como paridade referida a alguns, enquanto compartem os mesmos direitos por distinguirem-se como fortes ou fracos. Todavia, permanece a diferença mesmo entre os fortes e entre os fracos.

No lugar de enunciar o que deve ser dirigido ao conjunto dos homens, a ética de Nietzsche professa o que vem a ser, enquanto manifestação singular que diferencia os homens. Cada homem apresenta um devir diferente, dado expressar as lutas processadas apenas no seu organismo e, por isso, diferenciadas das que se dão em outro. Novamente, é 
o quanto de potência que se é que decide o vir-a-ser humano assim como a distinção irredutível entre homem e homem. De fato, Nietzsche situa o agir humano na perspectiva da explosão de força, isto é, na manifestação das lutas que se processam em profundidade. Assim, falar no que vem a ser é resgatar os processos não conscientes determinantes daquilo que se tem acesso através da consciência. Por isso, a necessidade manifesta-se no sentido de que só pode vir-a-ser aquilo que já se é, pois são as hierarquias resultantes das lutas que situam o homem na relação com outro homem. Nesse sentido, a ética nietzschiana remonta à sua interpretação fisiológica, trata-se da interpretação de uma multiplicidade de vontades de potência que se digladiam permanentemente e introduzem perspectivas que dotam a existência de sentido e de valor. Entretanto, não se trata de um princípio metafísico, explicar a ação desde a unidade da vontade, mas de interpretar a presença de uma multiplicidade de vontades enquanto acontecer. É na necessidade da luta e na perspectiva necessária enquanto resultado da disputa que se encontra, em Nietzsche, a possibilidade de interpretar o agir humano desde a necessidade e prescrever-lhe o amor enquanto aceitação do seu vir-a-se como fatum. 


\section{Referências:}

BERKOWITZ, P. Nietzsche the Ethics of an Inmoralist. Massachusetts: Harvard University Press, 1996.

DELEUZE, G. Nietzsche et la Philosophie. Paris: PUF, 1962. . Nietzsche e a filosofia. Trad. Edmundo Dias e Ruth Dias. Rio de Janeiro: Editora Rio, 1976.

HAAR, M. Par-delá le nihilisme. Paris: PUF, 1998.

HUME, D. Tratado de la naturaleza humana. Trad.Vicente Viqueira, Madrid: Calpe, 1923.

MAGNUS, B. Nietzsche's Existencial Imperative. Bloomington: Indiana University Press, 1978.

MARTON, S. Nietzsche, das forças cósmicas aos valores humanos. São Paulo: Brasiliense, 1990.

MOORE, E. Princípios éticos. In: Coleção os pensadores. Trad. Luiz João Baraúna, São Paulo: Abril Cultural, 1980.

MULLER-LAUTER. A doutrina da vontade de poder. Trad. Oswaldo Giacoia. São Paulo: Anna Blume, 1997.

NIETZSCHE, F. Sämtliche Werke- Kritische Studienausgabe, edição organizada por Giorgio Colli e Mazzino Montinari. Berlim: Walter de Gruyter \& Co., 1967/1978. 15 vol.

. Oeuvres philosophiques complètes. Edição organizada por Giorgio Colli e Mazzino Montinari. Paris: Gallimard, 1971/1997. 18 vol.

. Para além de bem e mal. Trad. Paulo César de Souza. São Paulo: Companhia das Letras, 1992.

. Genealogia da Moral. Trad. Paulo César de Souza, São Paulo: Brasiliense, 1987. 